\title{
EXAMINATION OF THE SUITABILITY OF DIFFERENT POLLINATORS FOR FOUR SWEET CHERRY CULTIVARS COMMONLY GROWN IN POLAND
}

\author{
Agnieszka GŁOWACKA*, Elżbieta ROZPARA \\ Research Institute of Horticulture \\ Konstytucji 3 Maja 1/3, 96-100 Skierniewice, Poland \\ Received: March 29, 2014; Accepted: May 8, 2014
}

\begin{abstract}
The aim of the work was to select pollinators for sweet cherry cultivars: 'Vanda', 'Techlovan', 'Sylvia' and 'Regina', which are of great economic significance in Poland. As pollinators, three or four different cultivars with the same or similar flowering time as the pollinated cultivars were evaluated annually. The pollinators belonged to different incompatibility groups. Pollination was carried out over four consecutive seasons. Assuming that for a good yield more than $20 \%$ of the flowers should develop fruits, a good pollinator for the cv. 'Vanda' was 'Techlovan', and for the cv. 'Regina' - 'Sylvia'. The cv. 'Techlovan' was pollinated to best effect by 'Vega', and the cv. 'Sylvia' by 'Regina', but the setting of fruits in the last two combinations was moderately good. Low to moderately good fruit setting but depending on the year was observed in the combinations 'Sylvia' $\times$ 'Summit', 'Regina' $\times$ 'Summit', and 'Regina' $\times$ 'Rainier'. Cultivar 'Summit' for 'Sylvia', and 'Summit' and 'Rainier' for the cv. 'Regina' should not be used as pollinators because the low percentage of fruit set obtained annually does not guarantee a satisfactory yield.
\end{abstract}

Key words: sweet cherry, pollinator, cultivar, fruit set

\section{INTRODUCTION}

Most of the cultivated varieties of sweet cherry are self-sterile. To set fruits, they require pollen from suitable pollinating varieties. Selection of pollinators for the cultivars of sweet cherry is difficult due to occurrence in this species incompatibility groups (Tehrani \& Brown 1992; Choi et al. 2002; Schuster 2012). Cultivars belonging to the same group cannot be effective pollinators for one another because of gametophytic self-incompatibility (GSI). This character in sweet cherry is attributed to a single multi-allelic gene (S), which controls the synthesis of proteins responsible for the incompatibility (Yamane et al. 2003). Fertilisation can occur only when the $S$-alleles in the haploid genome of the pollen grain differ from the S-alleles of the pistil genome (Wünsch \& Hormaza 2004). Currently, there are 27 known groups of infertility and two additional groups 0 and SC. To the group 0 belong cultivars that are universal pollen donors, while group SC constitute cultivars, which are universal donors and additionally are self-fertile (Bekefi 2006). According to the report of Tobutt et al. (2004), spontaneous mutations of alleles that occur in sweet cherry are the reason why so many additional groups of infertility are formed. Schuster et al. (2007) reported on additional nine new groups of infertility, which increased their number to 36.

Apart from GSI, a lack of fertilisation in sweet cherry may be caused by the difference in flowering time between the pollinated variety and the pollinator. Bekefi (2004), Tosun and Koyuncu (2007), Beyhan and Karakaş (2009), Moghadam et al. (2009) and Sutyemez (2011) emphasised that in addition to the GSI and difference in flowering time between an acceptor and a pollinator, the effectiveness of pollination and fertilisation in sweet cherry is also affected by a availability of pollinating insects and weather conditions, especially the temperature during flowering.

The aim of the study was to evaluate pollinators for four sweet cherry cultivars that are economically important in Poland: 'Vanda', 'Techlovan', 'Sylvia' and 'Regina'. According to Schuster (2012), 'Vanda' belongs to self-incompatibility Group XX, 'Techlovan' - VI, 'Sylvia' - IX and 'Regina' - II. 


\section{MATERIALS AND METHODS}

The study was conducted in the Experimental Orchard in Dąbrowice near Skierniewice in 20092012. Pollinators were tested for four sweet cherry cultivars: 'Vanda', 'Techlovan', 'Sylvia' and 'Regina' (given in the order of flowering). Trees grafted on F12/1 rootstock were planted in 2004, at a spacing of $4.7 \times 3 \mathrm{~m}$, and their canopies were formed into a spindle form.

Each year of the study, phenological observations were carried out in the beginning, full bloom and end of flowering. The beginning of flowering was taken as the day, on which $10 \%$ of the flowers on the tree were opened, full bloom $-75 \%$ of the flowers had opened, and in the end $-95 \%$ of the petals had fallen (Tzonev \& Yamaguchi 1999).

Weather conditions were recorded using weather station located in the experimental orchard. Starting from 2009, cross-pollination was performed for four consecutive seasons. When selecting pollinators, special attention was paid to make sure that the acceptor and the pollinator belong to different incompatibility groups (Table 1).

Pollination was carried out according to the methodology described by Choi and Andersen (2001). For each combination, at least 400 flowers were pollinated (100 flowers $\times 4$ replications). About a week before flowering, isolators were put on the branches selected for pollination to prevent accidental pollination. Pollination was performed on the next day after opening the flowers under isolators. Flowers with damaged pistils were removed before pollination.

Table 1. The pollination combinations used in the experiment

\begin{tabular}{ll}
\hline $\begin{array}{c}\text { Pollinated cultivar } \\
\text { (alleles) }\end{array}$ & \multicolumn{1}{c}{ Pollinators (alleles) } \\
\hline Vanda $\left(\mathrm{S}_{1} \mathrm{~S}_{6}\right)$ & $\begin{array}{l}\text { Techlovan }\left(\mathrm{S}_{3} \mathrm{~S}_{6}\right), \text { Summit }\left(\mathrm{S}_{1} \mathrm{~S}_{2}\right), \\
\text { Rainier }\left(\mathrm{S}_{1} \mathrm{~S}_{4}\right)\end{array}$ \\
\hline Techlovan $\left(\mathrm{S}_{3} \mathrm{~S}_{6}\right)$ & $\begin{array}{l}\text { Vanda }\left(\mathrm{S}_{1} \mathrm{~S}_{6}\right), \text { Vega }\left(\mathrm{S}_{2} \mathrm{~S}_{3}\right), \\
\text { Summit }\left(\mathrm{S}_{1} \mathrm{~S}_{2}\right), \text { Rainier }\left(\mathrm{S}_{1} \mathrm{~S}_{4}\right)\end{array}$ \\
\hline Sylvia $\left(\mathrm{S}_{1} \mathrm{~S}_{4}\right)$ & Regina $\left(\mathrm{S}_{1} \mathrm{~S}_{3}\right), \operatorname{Kordia}\left(\mathrm{S}_{3} \mathrm{~S}_{6}\right)$, \\
\hline Regina $\left(\mathrm{S}_{1} \mathrm{~S}_{3}\right)$ & Summit $\left(\mathrm{S}_{1} \mathrm{~S}_{2}\right)$ \\
\hline & Sylvia $\left(\mathrm{S}_{1} \mathrm{~S}_{4}\right), \operatorname{Kordia}\left(\mathrm{S}_{3} \mathrm{~S}_{6}\right)$, \\
& Summit $\left(\mathrm{S}_{1} \mathrm{~S}_{2}\right), \operatorname{Rainier}\left(\mathrm{S}_{1} \mathrm{~S}_{4}\right)$ \\
\hline
\end{tabular}

Pollen was collected at the stage of the white buds. The anthers were dried at room temperature. After drying, the pollen was stored in sealed glass vials, which were placed in a desiccator containing anhydrous calcium chloride. The pollen was deposited on the stigmas by hand, counting at the same time the number of pollinated flowers in each replication. Two weeks after pollination, the isolators were removed and fruitlets were counted, and at harvest the fruits obtained were counted.

The results on the percentage of fruit set in each pollination combination were analysed with analysis of variance using STATISTICA 10 software. The significance of the differences between means was assessed by Duncan's test at a 5\% significance level.

\section{RESULTS AND DISCUSSION}

\section{Phenological observations}

In all years of the study (2009-2012), the trees began flowering in the last decade of April and finished in the first decade of May. The period of flowering lasted from 10 to 14 days. During the years of the study, the flowering times of all the cultivars overlapped at least partially.

According to the classification presented by Moghadam et al. (2009), in terms of tree flowering time the sweet cherry, cultivars tested in the experiment were divided into three groups: group I 'Vanda' and 'Vega'; group II - 'Techlovan', 'Rainier', 'Summit' and 'Kordia' and group III 'Sylvia' and 'Regina'. Trees of the cultivars belonging to groups I and II bloomed at roughly the same time. Their flowering periods overlapped to the extent of $70 \%$. The flowering times of the trees belonging to groups I and III overlapped to the extent of $30-50 \%$. The course of tree flowering depended on the weather conditions, in particular, the temperature. It is only to be expected that during years with a different temperature pattern in the spring months, the flowering times of the cultivars of groups I and III may not overlap. For this reason, early varieties are not recommended as pollinators for late varieties, and vice versa (Bekefi 2004).

Over the period of the study, the weather conditions had a significant effect on the flowering period and the setting of fruits in sweet cherry. In 
2009 , the mean maximal temperature during flowering period reached $19^{\circ} \mathrm{C}$. The mean minimal temperature was low $\left(3.3^{\circ} \mathrm{C}\right)$ and the flowering period was long (Fig. 1). A few days before the flowering (19/20 April) there was a frost with a temperature drop to $-4{ }^{\circ} \mathrm{C}$. It caused damage to a portion of the flower buds in all the cultivars. The cross-pollination covered by the study was carried out a few days later. The flowers damaged by frosts had been removed before proceeding with the pollination. Another frost (15 May) with a temperature drop to $-1.8^{\circ} \mathrm{C}$ contributed to lowering the yield of 'Sylvia' trees.

In 2010, the mean maximal temperature was lower than in 2009 and reached $15.5^{\circ} \mathrm{C}$ but the mean minimal temperature was higher $\left(5.6^{\circ} \mathrm{C}\right)$. The length of flowering period was similar as in the year 2009 (Fig. 2). When the trees were blooming, the weather was windy and rainy. This had an impact on the percentage of pollinated flowers. In addition, still at the time when most of the cultivars had started flowering (22/23, 23/24 and 24/25 April), there were frosts with temperature drops to $-2.5^{\circ} \mathrm{C}$. They caused some of the cherry flowers within the isolators to freeze. In those conditions, the highest percentage of fruit was set by the trees of the late flowering cultivar 'Sylvia'. The other cultivars yielded poorly.

In 2011 the mean maximal temperature during flowering period reached $16.9{ }^{\circ} \mathrm{C}$. The mean minimal temperature was low $\left(2.9^{\circ} \mathrm{C}\right)$ and the flowering period was prolonged (Fig. 3). The weather conditions at the beginning of flowering were favourable to fruit setting. At night of 3/4 May, at a time when the trees of the early flowering cultivars were near the end of flowering, while those of the late cultivars were in full bloom, the temperature dropped to $1.5^{\circ} \mathrm{C}$. The most likely consequence of that cold weather event was extensive shedding of fruitlets.

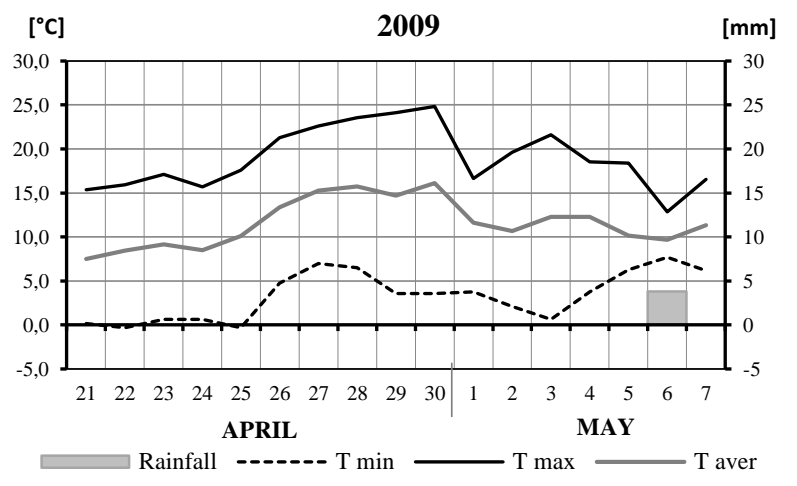

Fig. 1. Maximal, minimal and mean daily temperature and rainfall during flowering period in the year 2009

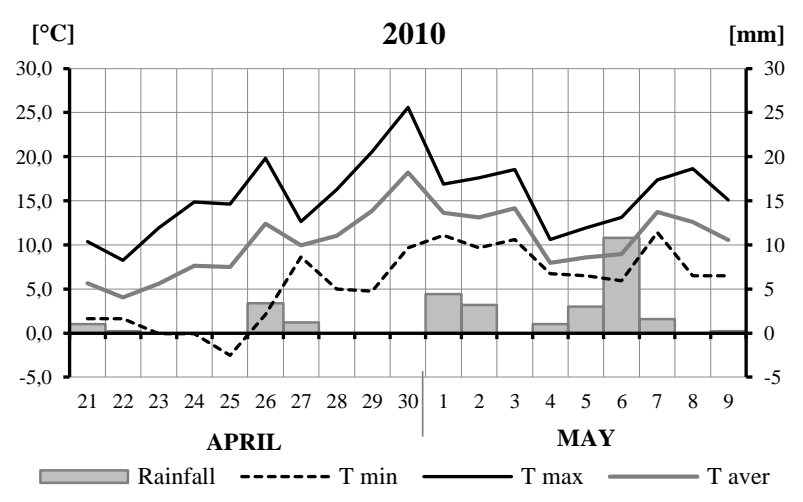

Fig. 2. Maximal, minimal and mean daily temperature and rainfall during flowering period in the year 2010

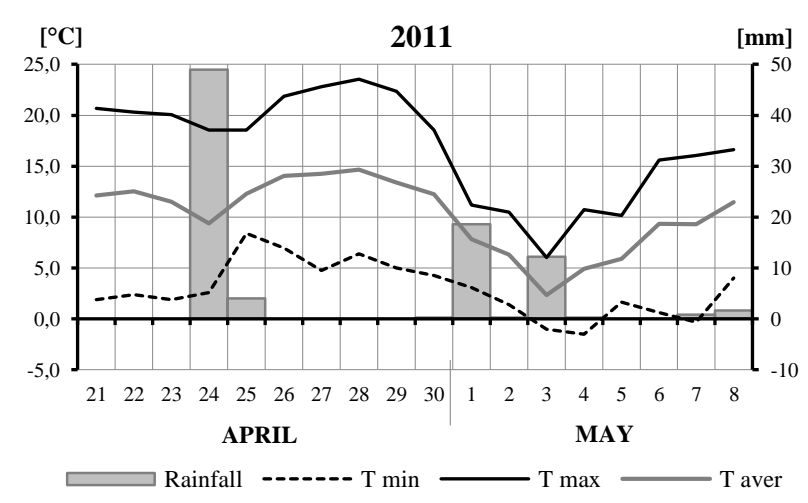

Fig. 3. Maximal, minimal and mean daily temperature and rainfall during flowering period in the year 2011 


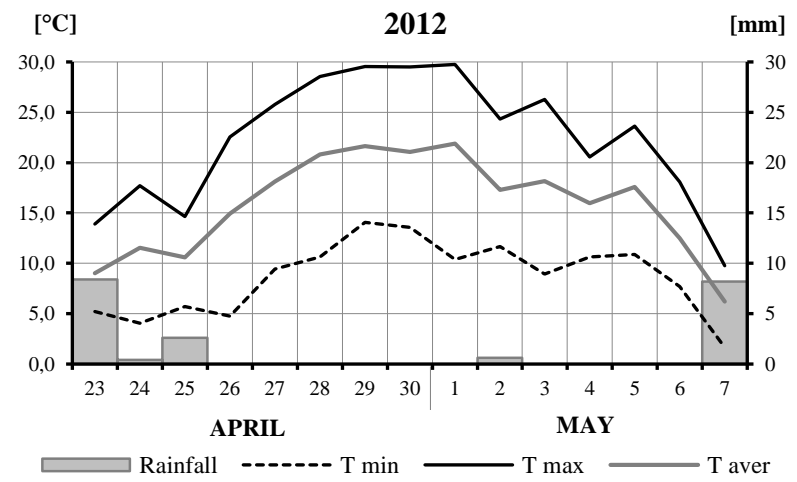

Fig. 4. Maximal, minimal and mean daily temperature and rainfall during flowering period in the year 2012

In 2012 the mean maximal temperature during flowering was high $\left(22.3^{\circ} \mathrm{C}\right)$. The mean minimal temperature reached $8.6^{\circ} \mathrm{C}$ and the flowering period was the shortest over the period of the study (Fig. 4). In April, just before the sweet cherry trees began to flower, a frost occurred with a temperature drop to $-5^{\circ} \mathrm{C}$. This resulted in damaging the flower buds of the cultivar 'Sylvia', and the trees yielded poorly but the other cultivars in the experiment yielded much better than 'Sylvia'.

The cultivars differed in terms of resistance to low temperatures. The differences among the cultivars, which were observed in the experiment, are consistent with the observations made by other authors (Choi \& Andersen 2001; Bekefi 2004; Tosun \& Koyuncu 2007; Lech et al. 2008; Beyhan \& Karakaş 2009; Moghadam et al. 2009; Sutyemez 2011).

\section{Cross-pollination results}

Over the 4 years of the study, the best-yielding trees were those of the cultivar 'Vanda'. The observed intervarietal differences in the percentage of fruit set were significant both 2 weeks after pollination and at the time of harvest.

The results of pollination of the flowers of the cultivar 'Vanda' with pollen of the cvs. 'Techlovan', 'Summit' and 'Rainier', obtained during the years 2009-2012 are presented in Table 2. All the cultivars tested proved to be good pollinators for the cultivar 'Vanda'. The best fruit setting and yielding by 'Vanda' trees were recorded in 2009, and the worst in 2010. The poor yielding in 2010 was probably the result of the spring frosts during flowering time (Fig. 2).
Table 2. Setting of fruits by the cultivar 'Vanda' in 20092012 depending on pollinator used

\begin{tabular}{lccccc}
\hline \multirow{5}{*}{$\begin{array}{c}\text { Pollinator } \\
\text { (cultivar) }\end{array}$} & \multicolumn{5}{c}{ Fruit set (\%) } \\
\cline { 2 - 5 } & 2009 & 2010 & 2011 & 2012 & Mean \\
\hline Two weeks after pollination \\
\hline Techlovan & $46.5 \mathrm{~b}$ & $35.4 \mathrm{a}$ & $41.9 \mathrm{a}$ & $53.4 \mathrm{a}$ & $44.3 \mathrm{a}$ \\
Summit & $60.3 \mathrm{a}$ & $32.1 \mathrm{a}$ & $23.8 \mathrm{~b}$ & $32.8 \mathrm{~b}$ & $37.3 \mathrm{~b}$ \\
Rainier & $60.9 \mathrm{a}$ & $25.8 \mathrm{~b}$ & $31.9 \mathrm{~b}$ & $26.0 \mathrm{~b}$ & $36.1 \mathrm{~b}$ \\
\hline \multicolumn{5}{c}{ At harvest } \\
\hline Techlovan & $33.9 \mathrm{a}$ & $5.5 \mathrm{a}$ & $19.9 \mathrm{a}$ & $29.2 \mathrm{a}$ & $22.1 \mathrm{a}$ \\
Summit & $42.8 \mathrm{a}$ & $2.7 \mathrm{a}$ & $15.0 \mathrm{a}$ & $15.8 \mathrm{~b}$ & $19.1 \mathrm{a}$ \\
Rainier & $39.9 \mathrm{a}$ & $4.2 \mathrm{a}$ & $14.7 \mathrm{a}$ & $13.4 \mathrm{~b}$ & $18.0 \mathrm{a}$ \\
\hline
\end{tabular}

The results of pollination of the flowers of the cultivar 'Techlovan' with pollen of the cvs. 'Vanda', 'Vega', 'Summit' and 'Rainier' are shown in Table 3. All of the tested cultivars proved to be suitable as pollinators for 'Techlovan' sweet cherry. Over the 4 years of the study, the most effective pollinator was 'Vega', and the least effective 'Vanda'. It is easy to notice that 'Techlovan' and 'Vega' bloomed at roughly in the same time. Regardless of the pollinator, the best setting of fruits of the cultivar 'Techlovan' was observed in 2009.

The results of pollination of the flowers of the $\mathrm{cv}$. 'Sylvia' with pollen of the cvs. 'Regina', 'Kordia' and 'Summit' are presented in Table 4. The trees of the cultivar 'Sylvia', unlike those of 'Vanda' and 'Techlovan', yielded best in 2010. It was the result of the late flowering time of trees of this cultivar. In 2010, the flowering proceeded under conditions favourable to both flower pollination and fertilisation. The highest percentage of fruit set in the cultivar 'Sylvia' was obtained in the combination in which 'Regina' was used as the pollinator. The least effective pollinator for 'Sylvia' was the cultivar 'Summit'.

The results of pollination of the flowers of the cultivar 'Regina' with pollen of the cvs. 'Sylvia', 'Kordia', 'Summit' and 'Rainier' are shown in Table 5. During the period 2009-2012 there were significant differences in the number of fruits being set by the cultivar 'Regina', which depended both on the pollinator and the year of the study. The best pollination results were obtained in the combination 'Regina' $\times$ 'Sylvia'. The highest percentage of fruit set in this combination was observed in 2010 and 2012. 
Table 3. Setting of fruit by the cultivar 'Techlovan' in 2009-2012 depending on pollinator used

\begin{tabular}{lccccc}
\hline \multirow{2}{*}{$\begin{array}{l}\text { Pollinator } \\
\text { (cultivar) }\end{array}$} & \multicolumn{5}{c}{ Fruit set (\%) } \\
\cline { 2 - 6 } & 2009 & 2010 & 2011 & 2012 & Mean \\
\hline \multicolumn{5}{c}{ Two weeks after pollination } \\
\hline Vanda & $17.4 \mathrm{c}$ & $12.9 \mathrm{~b}$ & $5.6 \mathrm{c}$ & $26.9 \mathrm{ab}$ & $15.7 \mathrm{~b}$ \\
Vega & $34.4 \mathrm{~b}$ & $20.8 \mathrm{ab}$ & $17.4 \mathrm{a}$ & $19.1 \mathrm{bc}$ & $23.0 \mathrm{a}$ \\
Summit & $31.8 \mathrm{~b}$ & $21.7 \mathrm{a}$ & $12.7 \mathrm{~b}$ & $28.6 \mathrm{a}$ & $23.7 \mathrm{a}$ \\
Rainier & $43.3 \mathrm{a}$ & $18.8 \mathrm{ab}$ & $14.5 \mathrm{ab}$ & $15.7 \mathrm{c}$ & $23.1 \mathrm{a}$ \\
\hline \multicolumn{6}{c}{ At harvest } \\
\hline Vanda & $10.4 \mathrm{c}$ & $6.5 \mathrm{~b}$ & $4.9 \mathrm{~b}$ & $18.4 \mathrm{a}$ & $10.1 \mathrm{~b}$ \\
Vega & $25.6 \mathrm{ab}$ & $13.5 \mathrm{a}$ & $10.6 \mathrm{a}$ & $13.9 \mathrm{ab}$ & $15.9 \mathrm{a}$ \\
Summit & $20.8 \mathrm{~b}$ & $0.6 \mathrm{c}$ & $6.4 \mathrm{~b}$ & $20.6 \mathrm{a}$ & $10.5 \mathrm{~b}$ \\
Rainier & $30.6 \mathrm{a}$ & $0.0 \mathrm{c}$ & $10.7 \mathrm{a}$ & $10.0 \mathrm{~b}$ & $14.4 \mathrm{a}$ \\
\hline
\end{tabular}

Table 4. Setting of fruit by the cultivar 'Sylvia' in 20092012 depending on pollinator used

\begin{tabular}{lrrrrr}
\hline \multirow{2}{*}{$\begin{array}{c}\text { Pollinator } \\
\text { (cultivar) }\end{array}$} & \multicolumn{5}{c}{ Fruit set (\%) } \\
\cline { 2 - 5 } & 2009 & 2010 & 2011 & 2012 & Mean \\
\hline \multicolumn{5}{c}{ Two weeks after pollination } \\
\hline Regina & $33.3 \mathrm{a}$ & $42.5 \mathrm{a}$ & $30.4 \mathrm{a}$ & $8.6 \mathrm{a}$ & $28.7 \mathrm{a}$ \\
Kordia & $12.4 \mathrm{c}$ & $41.7 \mathrm{a}$ & $17.6 \mathrm{~b}$ & $11.4 \mathrm{a}$ & $20.8 \mathrm{~b}$ \\
Summit & $16.7 \mathrm{~b}$ & $24.8 \mathrm{~b}$ & $11.3 \mathrm{~b}$ & $1.9 \mathrm{~b}$ & $13.7 \mathrm{c}$ \\
\hline \multicolumn{5}{c}{ At harvest } \\
\hline Regina & $21.3 \mathrm{a}$ & $34.0 \mathrm{a}$ & $14.4 \mathrm{a}$ & $6.9 \mathrm{a}$ & $19.2 \mathrm{a}$ \\
Kordia & $8.8 \mathrm{~b}$ & $33.3 \mathrm{a}$ & $8.2 \mathrm{~b}$ & $9.2 \mathrm{a}$ & $14.9 \mathrm{~b}$ \\
Summit & $11.0 \mathrm{~b}$ & $10.2 \mathrm{~b}$ & $7.0 \mathrm{~b}$ & $1.9 \mathrm{~b}$ & $7.5 \mathrm{c}$ \\
\hline
\end{tabular}

Table 5. Setting of fruit by the cultivar 'Regina' in 20092012 depending on pollinator used

\begin{tabular}{lrrrrr}
\hline Pollinator & \multicolumn{5}{c}{ Fruit set (\%) } \\
\cline { 2 - 5 } (cultivar) & 2009 & 2010 & 2011 & 2012 & Mean \\
\hline \multicolumn{7}{c}{ Two weeks after pollination } \\
\hline Sylvia & $29.7 \mathrm{~b}$ & $30.4 \mathrm{a}$ & $14.8 \mathrm{a}$ & $49.3 \mathrm{a}$ & $30.4 \mathrm{ab}$ \\
Kordia & $30.6 \mathrm{~b}$ & $26.9 \mathrm{a}$ & $14.0 \mathrm{a}$ & $37.9 \mathrm{a}$ & $27.3 \mathrm{~b}$ \\
Summit & $30.7 \mathrm{~b}$ & $28.6 \mathrm{a}$ & $10.7 \mathrm{a}$ & $39.3 \mathrm{a}$ & $27.3 \mathrm{~b}$ \\
Rainier & $52.2 \mathrm{a}$ & $32.0 \mathrm{a}$ & $16.4 \mathrm{a}$ & $39.6 \mathrm{a}$ & $35.1 \mathrm{a}$ \\
\hline \multicolumn{6}{c}{ At harvest } \\
\hline Sylvia & $19.9 \mathrm{~b}$ & $28.0 \mathrm{a}$ & $8.6 \mathrm{a}$ & $25.2 \mathrm{a}$ & $20.6 \mathrm{a}$ \\
Kordia & $22.0 \mathrm{~b}$ & $12.6 \mathrm{~b}$ & $7.4 \mathrm{a}$ & $20.6 \mathrm{a}$ & $13.5 \mathrm{~b}$ \\
Summit & $18.7 \mathrm{~b}$ & $2.1 \mathrm{c}$ & $5.8 \mathrm{a}$ & $17.9 \mathrm{a}$ & $8.6 \mathrm{~d}$ \\
Rainier & $33.0 \mathrm{a}$ & $2.2 \mathrm{c}$ & $8.6 \mathrm{a}$ & $18.7 \mathrm{a}$ & $9.8 \mathrm{c}$ \\
\hline
\end{tabular}

According to Bekefi (2004), in the case of an abundantly flowering sweet cherry trees, transformation of $10-20 \%$ of flowers into fruits gives a chance of obtaining a moderately high yield, while the setting of fruits by less than $10 \%$ of flowers results in a low yield. High yields of sweet cherries are achieved when fruits are set by $20-30 \%$ of the flowers, but if more than $30 \%$ a high quality of fruits is at risk. In the experiment described here, the degree of fruit setting varied significantly across the years of the study. According to the above classification, a very high degree of fruit setting was achieved in 2009 on trees of the cultivars 'Vanda' and 'Regina', and in 2010 - on trees of the cultivar 'Sylvia'. A low degree of fruit-setting was observed in 2010 on trees of the early flowering cultivars 'Vanda' and 'Techlovan', in 2011 - on trees of the late flowering cultivars - 'Sylvia' and 'Regina', and in 2012 - on trees of the cultivar 'Sylvia'.

The results indicate that weather conditions in winter or during tree flowering have a major influence on the rate of fruit setting by sweet cherry trees, which is consistent with the available literature (Hedhly et al. 2004; Tosun \& Koyuncu 2007; Lech et al. 2008; Beyhan \& Karakaş 2009; Moghadam et al. 2009; Sutyemez 2011).

Weather conditions, and especially the temperature, affect the time of effective pollination. Hedhly et al. (2004) reported that the optimum temperature for the growth of the pollen tube and for the fertilisation of flowers is about $20^{\circ} \mathrm{C}$. At a lower or higher temperature (about $30^{\circ} \mathrm{C}$ ) the growth of the pollen tube is much slower. In the experiment described here, the highest temperature during the flowering of sweet cherry trees was recorded in 2012 - the mean maximum temperature reached $22.3{ }^{\circ} \mathrm{C}$, mean minimum temperature $8.6{ }^{\circ} \mathrm{C}$ and mean daily temperature was $15.8^{\circ} \mathrm{C}$. Such temperatures were favourable to the setting of fruits by 'Vanda', 'Techlovan' and 'Regina' trees. Hedhly et al. (2004) and Lech et al. (2008) emphasise the beneficial effect of lower temperature on the setting of fruits, because it prolongs both the stigma receptivity and the period of effective fertilisation. Moreover, a temperature of $5{ }^{\circ} \mathrm{C}$ inhibits the ageing of ovules for up to 5 days from the beginning of flowering (Postweiler et al. 1985). It was confirmed by the 
results of our experiment, in which the best fruit set was obtained in 2009 when the mean maximum temperature reached $19^{\circ} \mathrm{C}$, mean minimum temperature $3.3{ }^{\circ} \mathrm{C}$ and mean daily temperature was $11.6^{\circ} \mathrm{C}$. Lower temperatures were recorded in 2010 and 2011 (mean maximum temperature $15.5^{\circ} \mathrm{C}$ and $16.9{ }^{\circ} \mathrm{C}$, respectively, mean minimum temperature $5.6{ }^{\circ} \mathrm{C}$ and $2.9^{\circ} \mathrm{C}$, respectively, mean daily temperature $10.5{ }^{\circ} \mathrm{C}$ and $10.2{ }^{\circ} \mathrm{C}$, respectively). At these temperatures, the setting of fruits could have been good if it had not been affected by late spring frosts.

Also well-known is the phenomenon of intersterility in sweet cherry and the fact that most cultivars require open pollination (Tehrani \& Brown 1992; Choi et al. 2002; Schuster 2012). In open-pollinated (self-sterile) varieties of sweet cherry, the setting of fruits is dependent upon the appropriate pollinator (Hormaza \& Herrero 1999; Choi \& Andersen 2001; Bekefi 2004; Tosun \& Koyuncu 2007; Lech et al. 2008; Beyhan \& Karakaş 2009; Sutyemez 2011). In the experiment presented here, good pollinators for the cultivar 'Vanda' proved to be: 'Techlovan', 'Summit' and 'Rainier'. Although in this cultivar, like in the other ones tested, the percentage of fruit set was different in the different years of the study, no significant differences were found in the number of fruits being depending on the pollinator. For the cultivar 'Techlovan', the most effective pollinator was 'Vega'. The other pollinators: 'Vanda', 'Summit' and 'Rainier' can also be recommended for the cultivar 'Techlovan'. Markedly lower fruit-set percentages in the cultivar 'Techlovan' under the influence of these three pollinators were observed in 2010 and 2011, which was probably the result of the spring frosts. The best pollinator for the cultivar 'Sylvia' was 'Regina', and a good one - also 'Kordia'. Choi and Anderson (2001) and Bekefi (2004) point out that among pollinators there are those that are only partially compatible with the cultivated varieties. Such a partially compatible pollinator is probably 'Summit' for the cultivar 'Sylvia', and 'Summit' and 'Rainier' for the cultivar 'Regina'. They should not be chosen as pollinators for these cultivars because the low percentage of fruit set obtained annually does not guarantee a satisfactory yield. The study shows that 'Sylvia' is a good pollinator for the cultivar 'Regina'.

\section{CONCLUSIONS}

1. Good pollinators for the cv. 'Vanda' proved to be 'Techlovan', 'Summit' and 'Rainier'.

2. For the cv. 'Techlovan', the most effective pollinator was 'Vega', and a good one also 'Rainier'.

3. The best pollinator for the cv. 'Sylvia' was 'Regina', and for the cv. 'Regina' - 'Sylvia'. A good pollinator for these cultivars was also 'Kordia'.

4. 'Summit' for the cv. 'Sylvia', and 'Summit' and 'Rainier' for the cv. 'Regina' should not be chosen as pollinators because the low percentage of fruit set does not guarantee a satisfactory yield.

\section{REFERENCES}

Bekefi Z. 2004. Self-fertility studies of some sweet cherry (Prunus avium L.) cultivars and selections. Int. J. Hort. Sci. 10(4): 21-26.

Bekefi Z. 2006. Review of sweet and sour cherry incompatibility. Int. J. Hort. Sci. 12(2): 111-116.

Beyhan N., Karakaş B. 2009. Investigation of the fertilisation biology of some sweet cherry cultivars grown in the Central Northern Anatolian Region of Turkey. Sci. Hort. 121(3): 320-326. DOI: 10.1016/j.scienta.2009.02.028.

Choi Ch., Andersen R.L. 2001. Variable fruit set in self-fertile sweet cherry. Can. J. Plant Sci. 81(4): 753-760.

Choi Ch., Tao R., Andersen R.L. 2002. Identification of self-incompatibility alleles and pollen in-compatibility groups in sweet cherry by PCR based s-allele typing and controlled pollination. Euphytica 123: 9-20. DOI: 10.1023/A:1014403802677.

Hedhly A., Hormaza J.I., Herrero M. 2004. Effect of temperature on pollen tube kinetics and dynamics in sweet cherry, Prunus avium (Rosaceae). Am. J. Bot. 91(4): 558-564. DOI: 10.3732/ajb.91.4.558.

Hormaza J.I., Herrero M. 1999. Pollen performance as affected by the pistilar genotype in sweet cherry (Prunus avium L.). Protoplasma 208: 129-135. DOI: $10.1007 / \mathrm{BF} 01279083$.

Lech W., Małodobry M., Dziedzic E., Bieniasz M., Doniec S. 2008. Biology of sweet cherry flowering. J. Fruit. Ornam. Plant Res. 16: 189-199.

Moghadam E.G., Hosseini P., Mokhtarian A. 2009. Blooming phenology and self-incompatibility of some commercial cherry (Prunus avium L.) cultivars in Iran. Sci. Hort. 123(1): 29-33. DOI: 10.1016/j.scienta.2009.07.013. 
Postweiler K., Strösser R., Anvari S.F. 1985. The effect of different temperatures on the viability of ovules in cherries. Sci. Hort. 25(3): 235-239. DOI: 10.1016/0304-4238(85)90120-7.

Schuster M. 2012. Incompatible (S-) genotypes of sweet cherry cultivars (Prunus avium L.). Sci. Hort. 148: 59-73. DOI: 10.1016/j.scienta.2012.09.012.

Schuster M., Flachowsky H., Köhler D. 2007. Determination of self-incompatible genotypes in sweet cherry (Prunus avium L.) accessions and cultivars of the German Fruit Gene Bank and from private collections. Plant Breeding 126(5): 533-540. DOI: 10.1111/j.1439-0523.2007.01401.x.

Sutyemez M. 2011. Pollen quality, quantity and fruit set of some self-compatible and self-incompatible cherry cultivars with artificial pollination. Afric. J. Biotechnol. 10(17): 3380-3386. DOI: 10.5897/AJB10.2013.

Tehrani G., Brown S.K. 1992. Pollen-incompatibility and self-fertility in sweet cherry. Plant Breeding Reviews, vol. 9, Janick J. (Ed.), John Wiley \& Sons, New York pp. 367-388. DOI: 10.1002/9780470650363.ch10.
Tobutt K.R., Sonneveld T., Bekefi T., Bošković R. 2004. Cherry (in)compatibility genotypes - an updated cultivar table. Acta Hort. 663: 667-672.

Tosun F., Koyuncu F. 2007. Investigations of suitable pollinator for 0900 Ziraat sweet cherry cv.: pollen performance tests, germination tests, germination procedures, in vitro and in vivo pollinations. Hort. Sci. (Prague) 34: 47-53.

Tzonev R., Yamaguchi M. 1999. Investigations on some far-east Prunus species: phenology. Acta Hort. 488: 239-242.

Wünsch A., Hormaz J.I. 2004. S-allele identification by PCR analysis in sweet cherry cultivars. Plant Breeding 123(4): 327-331. DOI:10.1111/j.1439-0523.2004.00984.x.

Yamane H., Ikeda K., Ushijima K., Sassa H., Tao R. 2003. A pollen-expressed gene for a novel protein with an F-box motif that is very tightly linked to a gene for S-RNase in two species of cherry, Prunus cerasus and Prunus avium. Plant Cell Physiol. 44(7): 764-769. DOI: $10.1093 / \mathrm{pcp} / \mathrm{pcg} 088$. 